歯周初期治療における Bacteroides forsythus, Porphyromonas gingivalis,

\title{
Actinobacillus actinomycetemcomitans $の$ 変動
}

—DNA プローブ法と PCR 法による測定

高 松 伸 博

東京医科歯科大学歯学部歯科保存学第二講座（指導：石川 烈教授）

(平成 9 年 9 月 30 日 受付)

\author{
The Effect of Periodontal Initial Therapy on Detection Frequency \\ of Bacteroides forsythus, Porphyromonas gingivalis, \\ and Actinobacillus actinomycetemcomitans \\ - Detection by DNA Probe and PCR Methods -
}

Nobuhiro Takamatsu

Department of Periodontology, Faculty of Dentistry, Tokyo Medical and Dental University

(Director : Prof. Isao Ishikawa)

\begin{abstract}
The purpose of this study was to examine microbiological changes after periodontal initial therapy by DNA probe and polymerase chain reaction (PCR) assays in addition to clinical evaluation. Twenty-six periodontitis patients, 10 males and 16 females, were selected. All subjects were treated by scaling and root planing following oral hygiene instruction. Bacterial samples were collected with paper points from a total of 104 sites, 4 sites in each patient, at baseline and after initial therapy. DNA probe analysis was used to monitor Bacteroides forsythus and Porphyromonas gingivalis. PCR analysis was performed to identify the presence of Actinobacillus actinomycetemcomitans. The initial therapy resulted in significant clinical improvements as assessed by clinical parameters including pocket depth, attachment level and bleeding on probing. After the therapy, the detection frequency of $B$. forsythus and $P$. gingivalis was significantly reduced, but the detection frequency of $A$. actinomycetemcomitans did not significantly decreased. These results indicated that initial therapy can bring about elimination of $B$. forsythus and $P$. gingivalis by means of conventional techniques, but not of $A$. actinomycetemcomitans. When complete elimination of these microorganisms was obtained, significant clinical improvement was found. Monitoring the changes of three bacteria may provide a more effective modality.
\end{abstract}

\section{I，緒言}

歯周炎は歯肉縁下ポケットにおいて歯一歯周組 織への細菌叢の定着と増殖により, 発症, 進行す
る疾患である。歯肉縁下の細菌叢は 250 種以上の 細菌を含むことが知られているが1)，なかでもい くつかの細菌あるいは細菌群がその歯周炎の進行 との密接な関連から歯周病原性細菌として認めら 
れている。歯周病原性細菌として Porphyromonas gingivalis, Bacteroides forsythus, Actinobacillus actinomycetemcomitans, Prevotella intermedia, Campylobacter rectus, Fusobacterium nucleatum といった細菌が報告されている ${ }^{2 \sim 11)}$ 。Renvert ら ${ }^{12)}$ はいくつかの歯周病原性細菌の除去を指標と

して歯周治療を行った結果，アタッチメントレベ ルの改善と $P$. gingivalis, A. actinomycetemcomitans の存在の有無に相関が認められ，C. rectus, Eikenella corrodens, F. nucleatum は治 療成功の指標とはならなかったことを報告してい る。また, Prevotella intermedia は歯肉縁下の感 染のコントロールにおいては根絶することは不可 能，または不必要であることを示唆する報告もあ る ${ }^{13)}$ 。歯周病原性細菌についての多くの研究のな かで, P. gingivalis, B. forsythus, $A$. actinomycetemcomitans はさまざまな型の歯周炎 に非常に強い関連性があると考えられている細菌 である ${ }^{14)}$

これまでのいくつかの報告4,15,16)では歯周治療 における診断, 治療法の選択, 評価の補助として, たとえば難しい症例に対して，アタッチメントロ スの予知に，これらの細菌をモニターすることを 勧めている。

歯周治療における初期治療とは原因となる因子 の除去を目的とした治療であり，そのなかで最も 重要な根面のスケーリング，ルートプレーニング の目的は細菌に污染されたセメント質の除去，お よび歯周ポケット内の病原性細菌の完全除去また は疾患を誘因しうるレベル以下にまで減少させる ことである。

これまで $P$. gingivalis やP. intermedia のよう な歯周病原性細菌は，機械的処置により除去，ま たは減少することが報告17,18)されているが $A$. actinomycetemcomitans は除去するのが困難であ $3^{19,20)}$ という報告もみられる。

一方， B. forsythus については初期治療による 除去効果についての報告はほとんどなく，その詳 細は不明であった。

しかしながら，歯周治療を成功させるにはこれ
ら 3 種の細菌の除去が欠くことのできない条件で あり，スケーリング，ルートプレーニングのほか に外科処置や，抗生剂の全身投与や局所投与に よってでもこれらの細菌の除去が必要であること が示唆されてきた。

本研究では, 中等度から重度の歯周炎患者にお いて初期治療が成功するか否かについて，従来の 臨床評価の基礎となる DNA プローブ法, PCR 法 を用いて歯周病原菌として最も強く事実として挙 げられている 3 菌種について遺伝子工学的評価に より検討を行った。

\section{II. 材料および方法}

\section{1. 被験者および被検部位}

被験者は東京医科歯科大学歯学部附属病院に来 院した患者のなかから，重篤な全身疾患がなく, 過去 6 力月以内に歯周治療を受けておらず，過去 3 力月以内に抗生物質の全身，局所投与を受けて いない中等度から重度の歯周炎患者 26 名（男性 10 名, 女性 16 名, 16 61 歳, 平均 38.5 歳, 成人 性歯周炎 11 名，早期発症型歯周炎 15 名）を選択 した。

Christersson ら ${ }^{21)}$ の報告を参考にサンプル採取 部位を選択した。サンプル採取（ベースライン） の 2 週間前に口腔内のポケット深さを 6 点法によ り測定を行い, 口腔内を上下左右に 4 分割し, 各 分画中，最も深い部位を被検部位とした。

\section{2. 臨床診查}

ベースライン，および再評価時に以下の臨床パ ラメータの測定を行った。

1）プロービングポケット深さ

ポケット探針を用い, 歯肉縁からポケット底部 までの距離を測定し，探針の目盛りの最も近い值 を $1 \mathrm{~mm}$ 単位で記録した。

2）プロービングアタッチメントレベル

ポケット探針を用い,セメントーエナメル境から ポケット底部までの距離を測定し，探針の目盛り の最も近い值を $1 \mathrm{~mm}$ 単位で記録した。

3）プロービング時の出血

プロービングポケット深さ，プロービングア 
タッチメントレベル測定後の出血の有無を記録し た。

\section{3. 細菌サンプル採取}

ベースライン，および再評価時に以下の方法で 遺伝子工学による細菌検査のための歯肉縁下の細 菌サンプルの採取を行った。被検部位を滅菌コッ トンロールにて簡易防湿後，歯肉縁上プラークを 滅菌綿球にて除去した。その後 2 本のペーパーポ イント（ジョンソンアブソーベントポイント $\mathrm{X}$ Fine：ジョンソンエンドジョンソン，東京）を歯 周ポケット底部まで挿入, 30 秒間静置した後それ ぞれ滅菌蒸留水 $100 \mu l$ (PCR 用), およびサンプル チューブ内の希釈液 (DNA プローブ用) のなかに 投入した。

\section{4. 細菌学的検查}

1) DNA プローブ法

B. forsythus, P. gingivalis の検出には DNA プ ローブ法を利用した Affirm DP ${ }^{\mathrm{TM}}$ Test (Becton Dickinson, Sparks, MD, U. S. A.) を用いた。 DNA プローブ法は細菌の持つ DNA の特異的な 塩基配列に相補的な塩基配列を有する DNA をプ ローブとして，標的となる細菌を検出するもので ある。これまではプローブの感度，特異性を高め るため，放射性同位元素により標識を行っていた こと, 検出まで数日かかること, 特殊な設備が必 要であることなどの点から，日常臨床への応用は 困難であった。今回用いたものは Becton Dickinson 社で試作されているもので，チェアサイドで 半自動的に P. gingivalis, B. forsythus, および $A$. actinomycetemcomitans の検出を行う，非放射性 DNA プローブ法を応用したキットである。この キットはサンプル, 希釈液, 緩衝液, 試薬カセッ ト, プローブ分析カード ( $\mathrm{PAC})$, サンプルライシ スブロック，Affirm ${ }^{\mathrm{TM}}{ }^{\mathrm{T}}$ ロセッサーからなる。 PACには細菌特異的なオリゴヌクレオチド DNA プローブを含む 3 つのビーズ，およびネが ティブ，ポジティブコントロールのビーズが埋め 込まれている。

歯肉縁下プラークを含むぺーパーポイントを Affirm $^{\mathrm{TM}}$ キットのサンプルチューブ内の希棌液
に投入した後，緩衝液にて処理し，ボルテックス ミキサーにて 1 分間攪汼, その後, ライシスブロッ クで $85^{\circ} \mathrm{C} て ゙ 5$ 分間加熱した。サンプルの菌液を試 薬カセットの 1 番目のウェルに加之, PAC ととも に Affirm ${ }^{\mathrm{TM}}$ プロセッサーにより, 自動処理を行っ た。1 番目のウェルで, 分析物のビーズ上のプロー ブへのハイブリダイゼーションが起こク，2 番目 のウェルでは発色プローブのハイブリダイゼー ションが起こる。ハイブリダイゼーションしな かったサンプルは 3 番目のウェルで洗い流され る。4 番目のウェルで発色プローブに酵素結合体 が結合する。結合しなかった酵素結合体と発色プ ローブは 5 番目と 6 番目のウェルで洗い流され る。酵素結合体がビーズ上に結合していれば，最 後の 7 番目のウェルで酵素基質により青く発色 し，ビーズが可視的に青くなれば標的細菌がポジ ティブであることを示す。ネガティブな結果はサ ンプル中の標的細菌の核酸の量が検出レベル以下 であることを示す。細菌検出感度については $10^{5}$ 個/サンプル以上で発色が確認された。この検出感

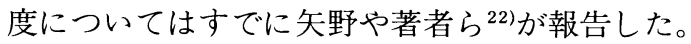

\section{2) PCR 法}

当初, A. actinomycetemcomitans についても DNA プローブ法を用いて検出を行ったが上記の $10^{5}$ 個/サンプルの検出レベルでは陽性のものが非 常に少なく臨床応用が不可能と考えられたので A. actinomycetemcomitans については PCR 法に よる検査を Ashimoto ら ${ }^{23,24)}$ の報告に基づいて 行った。ペーパーポイントを $100 \mu l$ の滅菌水中に 投入し，ボルテックスミキサーにて 1 分間覺拌, $100^{\circ} \mathrm{C} ， 10$ 分間加熱した後，水冷した。

プライマーとして $16 \mathrm{~S}$ rRNA 配列の一部を用 いた。配列は 5'-AAA CCC ATC TCT GAG TTC TTC TTC-3', 5'-ATG CCA ACT TGA CGT TAA AT-3’である。 $5 \mu l$ のサンプルを $10 \times$ PCR buffer (Promega, Madison, WI) $5 \mu l$, Taq DNA polymerase (Promega) 1.25 unit, 各 dNTP (Pharmacia LKB, Piscataway, NJ) $0.2 \mathrm{mM}$, $\mathrm{MgCl}_{2}$ を $1.5 \mathrm{mM}$ 含む reaction mixture に加え た。 
表 1 ベースライン, 再評価時の臨床パラメータの変化

\begin{tabular}{l|c|c}
\hline \hline & ベースライン & 再評価 \\
\hline ポケット深さ & $5.6 \pm 1.9 \mathrm{~mm}$ & $3.9 \pm 2.1 \mathrm{~mm} \star \star$ \\
アタッチメントレベル & $5.3 \pm 2.3 \mathrm{~mm}$ & $4.6 \pm 2.5 \mathrm{~mm} \star$ \\
プロービング時の出血 & $79 / 104$ 部位 & $54 / 104$ 部位 ${ }^{\star}$ \\
\hline
\end{tabular}

$\star \star: \mathrm{p}<0.01, \star \mathrm{p} \mathrm{p}<0.05$

表 2 ベースライン, 再評価時の細菌検出数

\begin{tabular}{l|c|c|c|c}
\hline \multirow{2}{*}{} & \multicolumn{2}{|c|}{ ベースライン } & \multicolumn{2}{|c}{ 再評価 } \\
\cline { 2 - 5 } & $\begin{array}{c}\text { 検出者数 }(\%) \\
(\mathrm{n}=26)\end{array}$ & $\begin{array}{c}\text { 検出部位数 }(\%) \\
(\mathrm{n}=104)\end{array}$ & $\begin{array}{c}\text { 検出者数 }(\%) \\
(\mathrm{n}=26)\end{array}$ & $\begin{array}{c}\text { 検出部位数 }(\%) \\
(\mathrm{n}=104)\end{array}$ \\
\hline B. forsythus & $26(100 \%)$ & $81(77.9 \%)$ & $17(65.4 \%)$ & $37(35.6 \%)$ \\
$P$. gingivalis & $22(84.6 \%)$ & $68(65.4 \%)$ & $13(50.0 \%)$ & $23(22.1 \%)$ \\
A. actinomycetemcomitans & $8(30.8 \%)$ & $17(16.4 \%)$ & $5(19.2 \%)$ & $9(8.7 \%)$ \\
\hline
\end{tabular}

PCR 増幅は DNA thermal cycler（PTC-200, MJ research, Boston, MA）を用いた。PCRの反 応温度は，最初の変性が $95^{\circ} \mathrm{C}, 2$ 分間，続いて 36 サイクルの変性 $\left(94^{\circ} \mathrm{C}, 30\right.$ 秒間), プライマーのア ニーリング $\left(55^{\circ} \mathrm{C}, 1\right.$ 分間 $)$, 伸長 $\left(72^{\circ} \mathrm{C}, 2\right.$ 分間 $)$ の後, 最終ステップ $72^{\circ} \mathrm{C} ， 10$ 分間に設定した。

PCR 産物を $4 \mathrm{~V} / \mathrm{cm}$ にて Tris-acetate EDTA buffer 中で，1.5\%アガロースゲル電気泳動にて 分析した。ゲルは ethidium bromide $0.5 \mu \mathrm{g} / \mathrm{m} l$ で染色し， $300 \mathrm{~nm}$ 紫外線ライト下で撮影を行っ た。分子量マーカーとして 1-kb DNA ladder digest (Life Technologies, Gaithersburg, MD) を用いた。

\section{5. 統計処理}

ベースラインと再評価時の臨床パラメータの変 化について Wilcoxon signed rank test を用いて 解析を行った。

ベースラインと再評価時の細菌検出の変化につ いて Wilcoxon signed rank test を用いて解析を 行った。

細菌の除去の有無によるポケット深さ，プロー ビングアタッチメントレベルの変化量の違いにつ
いて, unpaired t-test, Mann-Whitney U test を 用いて解析を行った。

\section{III. 結果}

\section{1. 臨床評価}

初期治療の期間は平均 8.4 力月であった。初期 治療により，全被験者のポケット梁さ，およびア タッチメントレベルは有意に改善した（それぞれ $\mathrm{p}<0.01, \mathrm{p}<0.05)$ 。また, プロービング時の出血 の認められた部位も有意に減少した $(p<0.01)$ (表 1)。

\section{2. 細菌検查}

前述のとおり，A. actinomycetemcomitans の検 出には本研究で用いた DNA プローブ法では検出 感度が低く，その変動を捉えることは困難と思わ れたため，PCR 法を用いた。以下に述べる細菌検 查結果のすべては B. forsythus, $P$. gingivalis につ いてはDNA プローブ法, A. actinomycetemcomitans については PCR 法によるものである。

被験者 26 名, 全 104 部位における各細菌の検出 被験者数, 検出部位数を表 2 に示す。B. forsythus はべースラインに 26 名, 81 部位で検出され, 再評 


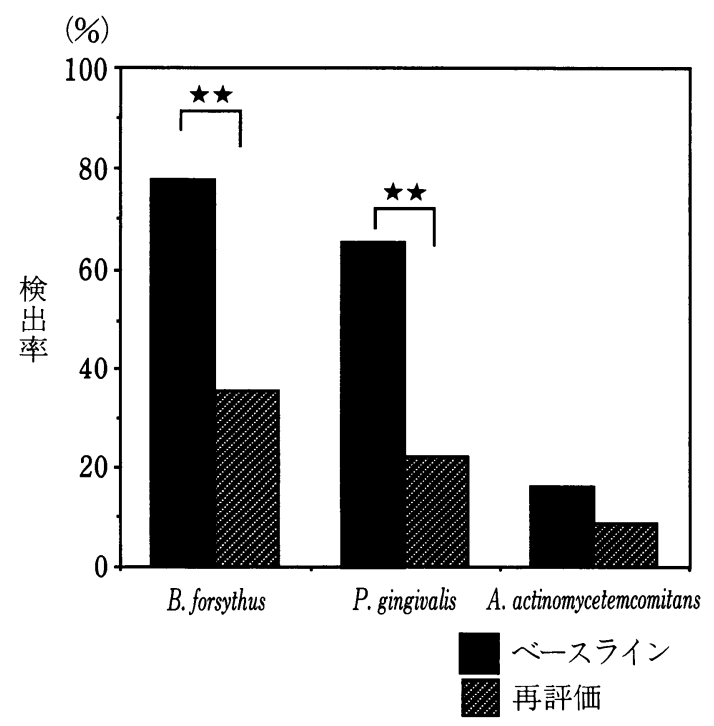

図 1 ベースライン, 再評価時の細菌検出率 $\star \star: \mathrm{p}<0.01$

価時では B. forsythus は 17 名，37 部位と有意な 検出部位数の減少が認められた $(\mathrm{p}<0.01)$ 。 $P$. gingivalis はベースラインに 22 名, 68 部位, 再評 価時では 13 名, 23 部位と有意な検出部位数の減 少が認められた $(\mathrm{p}<0.01)$ 。A. actinomycetemcomitans ではべースラインに 8 名, 17 部位で検 出され, 再評価時では 5 名, 9 部位で検出され, 有 意な減少は認められなかった（p>0.05）（図 1)。

表 3 に各細菌の関連性について示す。べースラ イン, 再評価時に同一部位に検出された細菌の組 み合わせは B. forsythus と P. gingivalis が最も多 く, 次いでB. forsythus のみ, 3 菌種とも検出され たものが多かった。P. gingivalis が単独で検出さ れた部位はべースラインの 1 部位のみで，ほかの 2 菌種と存在した部位が多かった。特に $B$. for sythus とともに検出される割合が高く，P. gingivalisの検出された部位中, ベースラインで $97.1 \%$, 再評価時で $100 \%$ 部位で同時に検出さ れた。

\section{3. 臨床的変化と細菌の変化}

ベースラインにそれぞれの細菌が検出された部 位における，再評価時の細菌の検出の有無による ポケット深さの改善量は B. forsythus では非検出
表 3 ベースライン, 再評価時の検出細菌の関係

\begin{tabular}{|c|c|c|}
\hline \multirow{2}{*}{ 歯周病原性細菌 } & \multicolumn{2}{|c|}{ 検出部位数 (\%) } \\
\hline & ベースライン & 再評価 \\
\hline A. a. $\left(\right.$ all $\left.^{\dagger}\right)$ & $17(16.3 \%)$ & $9(8.7 \%)$ \\
\hline A. a. (alone $\left.{ }^{\neq}\right)$ & $4(3.8 \%)$ & $4(3.8 \%)$ \\
\hline B. f. $\left(\right.$ all $\left.^{\dagger}\right)$ & $81(77.9 \%)$ & $37(35.6 \%)$ \\
\hline B. f. (alone $\left.{ }^{\neq}\right)$ & $11(10.6 \%)$ & $13(12.5 \%)$ \\
\hline P. g. $\left(\right.$ all $\left.^{\dagger}\right)$ & $68(65.4 \%)$ & $24(23.1 \%)$ \\
\hline P. g. (alone $\left.{ }^{\neq}\right)$ & $1(0.9 \%)$ & $0(0.0 \%)$ \\
\hline A. a. + B.f. & $4(3.8 \%)$ & $0(0.0 \%)$ \\
\hline A. a. +P. g. & $1(0.9 \%)$ & $0(0.0 \%)$ \\
\hline A. a. + B. f. +P. g. & $8(7.7 \%)$ & $5(4.8 \%)$ \\
\hline B. f. $+P . g$ & $58(55.8 \%)$ & $19(18.3 \%)$ \\
\hline
\end{tabular}

A. a. : A. actinomycetemcomitans

部位で $2.46 \mathrm{~mm}$, 検出部位で $0.85 \mathrm{~mm}$, プロービ ングアタッチメントレベルの変化はそれぞれ $1.07,-0.31 \mathrm{~mm}$ であり, 再評価時の細菌の非検 出部位と検出部位の間でポケット深さ, プロービ ングアタッチメントレベルの変化に有意な差が認 められた（それぞれ $\mathrm{p}<0.01 ， \mathrm{p}<0.05 ）($ 図 2)。

P. gingivalis ではポケット深さの改善量は非検 出部位で $2.20 \mathrm{~mm}$, 検出部位で $0.47 \mathrm{~mm}$, プロー ビングアタッチメントレベルの変化はそれぞれ 0.65, $0.05 \mathrm{~mm}$ で, ポケット深さの改善量に非検 出部位と検出部位の間で有意な差が認められた $(\mathrm{p}<0.05)$ (図 3$)$ 。

A. actinomycetemcomitans ではポケット染さ の改善量は非検出部位で $2.29 \mathrm{~mm}$, 検出部位で $0.13 \mathrm{~mm}$, プロービングアタッチメントレベルの 変化はそれぞれ $1.48,-0.38 \mathrm{~mm}$ であり, 再評価 時の細菌の非検出部位と検出部位の間でポケット 梁さ, プロービングアタッチメントレベルの変化 に有意な差が認められた（それぞれ $\mathrm{p}<0.05, \mathrm{p}<$ 0.05）（困 4）。

以上のようにB. fosythus, P. gingivalis, およ び A. actinomycetemcomitans, いずれの菌におい ても術前に検出されていて, 術後検出されなかっ 


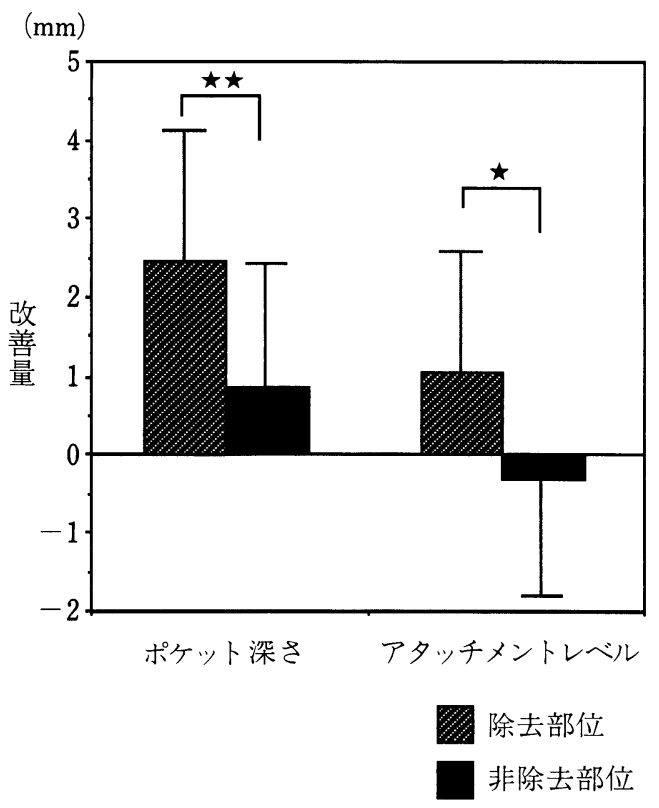

図 2 細菌の除去によるポケット深さ, アタッチ メントレベルの改善量 (B. forsythus)

$\star \star: \mathrm{p}<0.01, \star \mathrm{p}: \mathrm{p}<0.05$

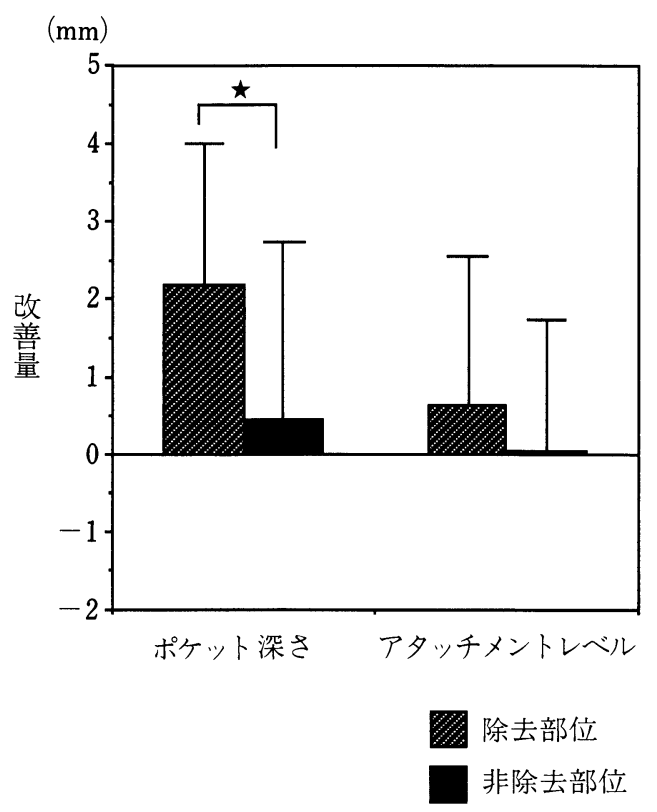

図 3 細菌の除去によるポケット深さ,アタッ チメントレベルの改善量 ( $P$. gingivalis)

$\star: \mathrm{p}<0.05$

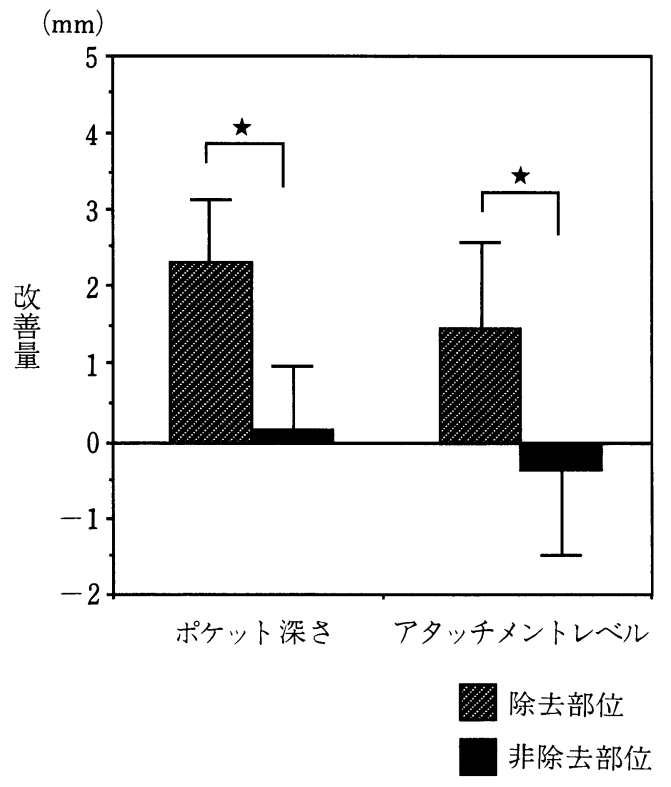

図 4 細菌の除去によるポケット媣さ,アタッチ メントレベルの改善量 (A. actinomycetemcomitans)

$\star: \mathrm{p}<0.05$

た部位では有意な歯周組織の改善が認められた。 一方，これらの細菌が初期治療後も見いだされた 部位では初期治療による改善が認められなかった ク、一部では悪化していた。

\section{IV. 考察}

これまでの多くの報告において歯周炎患者にお いて, B. forsythus, $P$. gingivalis, $A$. actinomycetemcomitans の 3 菌種がその病因との 強い関連性を示すことが認められている2 11)。

口腔衛生指導, スケーリング, ルートプレーニ ングを施した中等度から重度の 26 名の歯周炎患 者において, 多くの部位で, ポケット深さやアタッ チメントレベルの改善, またプロービング時の出 血の消退が認められた。しかしながら, 臨床症状 の改善がみられない部位, 悪化した部位も認めら れた。

本研究ではベースラインにおいて, B. forsythus が全被験者から検出され, 全 104 部位中 $77.9 \%$ の 
部位で検出された。この検出頻度は Lai ( $^{8)}$ の報 告と同様であった。しかしながら, Kamma ら ${ }^{25}$ は 重度の歯周炎の若い成人に扔ける細菌培養法によ る検出頻度は $53.4 \%$ であったと報告している。B. forsythus は培養法による検出が困難であ $\eta^{25,26)}$, DNA プローブ27 31)や蛍光抗体法 ${ }^{11,32 ~ 34)}$ の検出も多く行われてきた。矢野ら ${ }^{22)} の$ 報告では 細菌培養法と本研究でも用いた DNA プローブ法 によるB. forsythus の検出の比較を行い，DNA プローブ法を用いた方法のほうが検出感度が高い ことを示した。また矢野 ${ }^{35}$ は, B. forsythus の存在 とポケット深さ，プロービング時の出血，骨吸収 度との間に相関が認められたことより，本菌の歯 周組織破壊における役割，およびその除去の重要 性を示唆している。

B. forsythus に対するスケーリング，ルートプ レーニングの効果についての報告は少ない。清 田 ${ }^{36)}$ の蛍光抗体法を用いた研究によるとスケーリ ング,ルートプレーニングにより, 5 部位中 3 部位 (60\%) でB. forsythus が除去されたという。本研 究ではべースラインにB. forsythus が検出された 81 部位のうち初期治療終了後には50部位 (61.7\%) が検出限界以下に除去された。このこと はスケーリング，ルートプレーニングという機械 的処置が B. forsythus の除去に効果的であること を示唆するものと思われる。

ベースラインにP. gingivalis が検出された部 位のうち $97.1 \%$ の部位で B. forsythus も同時に 検出され，初期治療終了後では $100 \%$ であった。こ れは蛍光抗体法を用いた研究で $P$. gingivalis と B. forsythus が同時に検出されるという Gmür ら の報告 ${ }^{10)}$ と一致する。これは両菌種の存在する要 求環境が似たものであることを示唆しているのか もしれない。

ベースラインにP. gingivalis が検出された 78 部位のうち初期治療終了後には 50 部位（64.1\%） が検出限界以下に除去された。これはスケーラー による機械的な処置がP. gingivalis の除去に有 効であるという報告 ${ }^{18)}$ とほぼ一致する。

ベースラインに A. actinomycetemcomitans が
検出された 8 名のうち, 初期治療により $A$. actinomycetemcomitans が検出されなかったのは 3 名 $(37.5 \%)$ であった。この結果は $A$. actinomycetemcomitans を除去するのが困難であ るという多くの報告 ${ }^{19,20)}$ と一致する。この細菌に ついては，その組織侵入性が歯周組織破壊におい て重要な病原性のメカニズムであること䭪,38)が示 唆されている。

細菌の除去と臨床パラメータの変化については B. forsythus, A. actinomycetemcomitans の除去 により，ポケット深さとプロービングアタッチメ ントレベルの有意な改善が認められた。また $P$. gingivalis の除去された部位ではポケット深さの 有意な減少が認められた。

この結果はこれら歯周病原性細菌の除去が臨床 症状の改善に重要であることを示唆している。深 いポケットや分岐部を含むポケットは十分なス ケーリング，ルートプレーニングを正確に行うこ

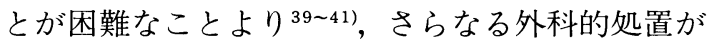
必要と思われる。 $\mathrm{Ali}^{42)}$ らは歯周外科処置により, P. gingivalis, A. actinomycetemcomitans などの 歯周病原性細菌の検出頻度が減少することを示し ている。しかしながら，A，actinomycetemcomitans は外科処置のみでも完全に除去するこ とが困難であり ${ }^{43)}$ ，抗生剂の投与が有効であると する報告 ${ }^{44 \sim 46)}$ もある。

本研究で行ったように 3 種の歯周病原性細菌の 変動をモニターすることは, 抗生剤の使用も含め, 歯周治療でより効果的な方法を採ることができ, より正確な処置を可能にし, 臨床効果から予後の 判定までもより科学的，客観的な方法になると思 われる。これまでの歯周治療においてはこのよう な細菌学的なパラメー夕はいっさい用いられず, 臨床的なパラメータのみで行われてきた。今回用 いたようなチェアサイドにおけるDNAプロー ブ，またはより検出感度の高い PCR 法による細 菌検查を治療の一環に加えることが将来可能とな るであろう。 


\section{謝辞}

稿を終えるにあたり終始ご懇篤なるご指導とご校 閲を賜わりました本学歯学部歯科保存学第二講座の 石川 烈教授に深甚なる感謝の意を表します。また本 研究に際しご指導, ご協力いただきました歯科保存学 第二講座の諸先生方のご厚意に深謝いたします。

\section{文献}

1) Moore, W. E. C., Holdeman, L. V., Cato, E. P., Smibert, R. M., Burmeister, J. A., Palcanis, K. G. and Ranney, R. R . : Comparative bacteriology of juvenile periodontitis. Infect. Immu. 48(2) : 507-519, 1985.

2) Bragd, L., Dahlén, G., Wikström, M. and Slots, J.: The capability of Actinobacillus actinomycetemcomitans, Bacteroides gingivalis and Bacteroides intermedius to indicate progressive periodontitis; a retrospective study. J. Clin. Periodontol. 14(2) : 95-99, 1987.

3) Dzink, J. L., Socransky, S. S., Ebersole, J. L. and Frey, D. E. : ELISA and conventional techniques for identification of black-pigmented Bacteroides isolated from periodontal pockets. J. Periodont. Res. 18(4) : 369-374, 1983.

4) Slots, J., Bragd, L., Wikström, M. and Dahlén, G.: The occurrence of Actinobacillus actinomycetemcomitans, Bacteroides gingivalis and Bacteroides intermedius in destructive periodontal disease in adults. J. Clin. Periodontol. $13(6): 570-577,1986$.

5) Slots, J. and Genco, R. J. : Black-pigmented Bacteroides species, Capnocytophaga species, and Actinobacillus actinomycetemcomitans in human periodontal disease; virulence factors in colonization, survival, and tissue destruction. J. Den. Res. 63 (3) : 412-421, 1984.

6) Tanner, A. C., Haffer, C., Bratthall, G. T., Visconti, R. A. and Socransky, S. S. : A study of the bacteria associated with advancing periodontitis in man. J. Clin. Periodontol. 6(5) : 278-307, 1979.

7) Dzink, J. L., Tanner, A. C., Haffajee, A. D. and Socransky, S. S. : Gram negative species associated with active destructive periodontal lesions. J. Clin. Periodontol. $12(8): 648-659$, 1985.

8) Lai, C. H., Listgarten, M. A., Shirakawa, M. and Slots, J.: Bacteroides forsythus in adult gingivitis and periodontitis. Oral Microbiol. Immunol. 2(4) : 152-157, 1987.
9) Haffajee, A. D., Socransky, S. S., Dzink, J. L., Taubman, M. A. and Ebersole, J. L. : Clinical, microbiological and immunological features of subjects with refractory periodontal diseases. J. Clin. Periodontol. 15(6) : 390-398, 1988.

10) Gmür, R., Strub, J. R. and Guggenheim, B. : Prevalence of Bacteroides forsythus and Bacter. oides gingivalis in subgingival plaque of prosthodontically treated patients on short recall. J. Periodont. Res. 24(2) : 113-120, 1989.

11) Christersson, L. A., Fransson, C. L., Dunford, R. G. and Zambon, J. J. : Subgingival distribution of periodontal pathogenic microorganisms in adult periodontitis. J. Periodontol. 63(5) : 418-425, 1992.

12) Renvert, S., Dahlén, G. and Wikström, M. : Treatment of periodontal disease based on microbiological diagnosis. Relation between microbiological and clinical parameters during 5 years. J. Periodontol. 67 (6) : 562-571, 1996.

13) Slots, J., Emrich, L. J., Genco, R. J. and Rosling, B. G. : Relationship between some subgingival bacteria and periodontal pocket depth and gain or loss of periodontal attachment after treatment of adult periodontitis. J. Clin. Periodontol. $12(7): 540-552,1985$.

14) Zambon, J. J. : Periodontal disease ; Microbial factors. The American Academy of Periodontology. : Ann. Periodontol. 1. Virginia, 1996, Lansdowne, 879-925.

15) Slots, J. and Listgarten, M. A. : Bacteroides gingivalis, Bacteroides intermedius and Actinobacillus actinomycetemcomitans in human periodontal diseases. [Review] [96 refs] J. Clin. Periodontol. 15(2) : 85-93, 1988.

16) Wennstrom, J. L., Dahlén, G., Svensson, J. and Nyman, S.: Actinobacillus actinomycetemcomitans, Bacteroides gingivalis and Bacteroides intermedius ; predictors of attachment loss? Oral Microbiol. Immunol. 2(4) : 158-162, 1987.

17) Hinrichs, J. E., Wolff, L. F., Pihlstrom, B. L., Schaffer, E. M., Liljemark, W. F. and Bandt, C. L. : Effects of scaling and root planing on subgingival microbial proportions standardized in terms of their naturally occurring distribution. J. Periodontol. 56 (4) : 187-194, 1985.

18) van Winkelhoff, A. J., van der Velden, U. and de Graaff, J. : Microbial succession in recolonizing deep periodontal pockets after a single course of supra- and subgingival debridement. J. Clin. Periodontol. 15(2) : 116-122, 1988. 
19) Renvert, S., Wikström, M., Dahlén, G., Slots, J. and Egelberg, J. : Effect of root debridement on the elimination of Actinobacillus actinomycetemcomitans and Bacteroides gingivalis from periodontal pockets. J. Clin. Periodontol. 17 (6) : 345-350, 1990.

20) Renvert, S., Wikström, M., Dahlén, G., Slots, J. and Egelberg, J. : On the inability of root debridement and periodontal surgery to eliminate. Actinobacillus actinomycetemcomitans from periodontal pockets. J. Clin. Periodontol. $17(6): 351-355,1990$.

21) Christersson, L. A., Fransson, C. L., Dunford, R. G. and Zambon, J. J. : Subgingival distribution of periodontal pathogenic microorganisms in adult periodontitis. J. Periodontol. 63(5): 418-425, 1992 .

22）矢野和子, 高松伸博, 何 濤, 梅田誠, 石川 烈：非放射性 DNA プローブ（Affirm DP ${ }^{\circledR}$ ) の 歯周病原性細菌の検出能について。 口病誌 63(3) : 482-488, 1996.

23) Ashimoto, A., Chen, C., Bakker, I. and Slots, J. : Polymerase chain reaction detection of 8 putative periodontal pathogens in subgingival plaque of gingivitis and advanced periodontitis lesions. [Journal Article] Oral Microbiol. Immunol. 11(4): 266-273, 1996.

24) Slots, J., Ashimoto, A., Flynn, M. J., Li, G. and Chen, C. : Detection of putative periodontal pathogens in subgingival specimens by $16 \mathrm{~S}$ ribosomal DNA amplification with the polymerase chain reaction. Clin. Infect. Dis. 20 (suppl 2) : S 304-307, 1995.

25) Kamma, J. J., Nakou, M. and Manti, F. A. : Predominant microflora of severe, moderate and minimal periodontal lesions in young adults with rapidly progressive periodontitis. [Journal Article] J. Periodont. Res. 30(1): 66-72, 1995.

26) Dzink, J. L., Socransky, S. S. and Haffajee, A. D. : The predominant cultivable microbiota of active and inactive lesions of destructive periodontal diseases. J. Clin. Periodontol. 15(5) : 316-323, 1988.

27) Loesche, W. J., Lopatin, D. E., Stoll, J., van Poperin, N. and Hujoel, P. P. : Comparison of various detection methods for periodontopathic bacteria; can culture be considered the primary reference standard? J. Clin. Microbiol. $30(2): 418-426,1992$.

28) Lotufo, R. F., Flynn, J., Chen, C. and Slots, J. : Molecular detection of Bacteroides forsythus in human periodontitis. Oral Microbiol. Im- munol. 9(3) : 154-160, 1994

29) Ali, R. W., Skaug, N., Nilsen, R. and Bakken, V. : Microbial associations of 4 putative periodontal pathogens in Sudanese adult periodontitis patients determined by DNA probe analysis. J. Periodontol. 65(11) : 1053-1057, 1994.

30) Ali, R. W., Bakken, V., Nilsen, R. and Skaug, N. : Comparative detection frequency of 6 putative periodontal pathogens in Sudanese and Norwegian adult periodontitis patients. J. Periodontol. 65(11) : 1046-1052, 1994.

31) Listgarten, M. A., Wong, M. Y. and Lai, C. H. : Detection of Actinobacillus actinomycetemcomitans, Porphyromonas gingivalis, and Bacteroides forsythus in an A. actinomycetemcomitans-positive patient population. J. Periodontol. 66(2) : 158-164, 1995.

32) Gmür, R., Werner-Felmayer, G. and Guggenheim, B. : Production and characterization of monoclonal antibodies specific for Bacteroides gingivalis. Oral Microbiol. Immunol. 3(4) : 181-186, 1988.

33) Gmür, R., Strub, J. R. and Guggenheim, B. : Prevalence of Bacteroides forsythus and Bacter. oides gingivalis in subgingival plaque of prosthodontically treated patients on short recall. J. Periodont. Res. 24 (2) : 113-120, 1989.

34) Listgarten, M. A., Lai, C. H. and Young, V. : Microbial composition and pattern of antibiotic resistance in subgingival microbial samples from patients with refractory periodontitis. J. Periodontol. 64(3) : 155-161, 1993.

35）矢野和子：細菌培養法と DNA プローブによる 七卜歯肉縁下細菌叢の Bacteroides forsythus の 検索とその歯周疾患との関連性について。目歯周 誌 39(1) : 1-11，1997.

36）清田 築：蛍光抗体法による歯周炎局所細菌叢 の検討および初期治療の評価について。 日歯周誌 31(1) : 29-42, 1989.

37) Saglie, F. R., Marfany, A. and Camargo, P. : Intragingival occurrence of Actinobacillus actinomycetemcomitans and Bacteroides gin givalis in active destructive periodontal lesions. J. Periodontol. 59(4) : 259-265, 1988.

38) Carranza, F. A. Jr., Saglie, R., Newman, M. G. and Valentin, P. L. : Scanning and transmission electron microscopic study of tissue-invading microorganisms in localized juvenile periodontitis. J. Periodontol. 54(10) : 598-617, 1983.

39) Caffesse, R. G., Sweeney, P. L. and Smith, B. 
A. : Scaling and root planing with and without periodontal flap surgery. J. Clin. Periodontol. 13(3) : 205-210, 1986.

40) Nordland, P., Garrett, S., Kiger, R., Vanooteghem, R., Hutchens, L. H. and Egelberg, J. : The effect of plaque control and root debridement in molar teeth. J. Clin. Periodontol. 14(4): 231-236, 1987.

41) Loos, B., Nylund, K., Claffey, N. and Egelberg, J. : Clinical effects of root debridement in molar and non-molar teeth. A 2-year followup. J. Clin. Periodontol. 16 (8) : 498-504, 1989.

42) Ali, R. W., Lie, T. and Skaug, N. : Early effects of periodontal therapy on the detection frequency of four putative periodontal pathogens in adults. J. Periodontol. 63(6) : 540-547, 1992.

43) Christersson, L. A., Slots, J., Rosling, B. G. and
Genco, R. J. : Microbiological and clinical effects of surgical treatment of localized juvenile periodontitis. J. Clin. Periodontol. 12 (6) : 465-476, 1985.

44) Slots, J. and Rosling, B. G. : Suppression of the periodontopathic microflora in localized juvenile periodontitis by systemic tetracycline. J. Clin. Periodontol. 10 (5) : 465-486, 1983.

45) Mandell, R. L. and Socransky, S. S. : Microbiological and clinical effects of surgery plus doxycycline on juvenile periodontitis. J. Periodontol. 59(6) : 373-379, 1988.

46) Goene, R. J., Winkel, E. G., Abbas, F., Rodenburg, J. P., van Winkelhoff, A. J., and de Graaff, J.: Microbiology in diagnosis and treatment of severe periodontitis. A report of four cases. J. Periodontol. 61 (1) : 61-64, 1990. 